\title{
Passerine bird pollination and fruiting behaviour in a dry sea- son blooming tree species, Erythrina suberosa Roxb. (Fabaceae) in the Eastern Ghats forests, India
}

\author{
Aluri J. S. RAJU\# and Srungavarapu P. RAO \\ Department of Environmental Sciences, Andhra University, Visakhapatnam 530 003, India
}

\section{ORNITHOLOGICAL SCIENCE \\ (c) The Ornithological Society of Japan 2004}

\begin{abstract}
Erythrina suberosa blooms during the dry-season. The flowers are large, papilionaceous, and partly self-compatible. The floral characteristics provide an example of ornithophilous pollination; all the flowers are pollinated exclusively by passerine birds. The fruit set rate was only $10 \%$, but this was compensated for by a higher seed set rate. The flowers normally produce seven ovules, with those in the number two and five positions appearing to be the most preferred for seed development.
\end{abstract}

Key words Breeding system, Erythrina suberosa, Fruiting behaviour, Passerine birds, Pollination
Bird pollination is as important as insect pollination in the tropics and in southern temperate zones. About 100 families of flowering plants are known to have at least some members adapted for bird-pollination (Meeuse \& Morris 1984). The family Fabaceae includes species pollinated by insects and others pollinated by birds; although the type of flower remains essentially similar, the bird-pollinated flowers show marked differences in structure related to this method of pollination. In insect-pollinated species, the flowers have wings and a keel forming an alighting platform for insects, which in so doing set off a remarkable trigger mechanism that delivers pollen onto the bodies of the insects. These parts of the flower are more or less suppressed when birds are the agents of pollination, and for this reason the trigger mechanism is absent in bird-pollinated species (Jaeger 1961). The genus Erythrina provides a typical example of bird pollination within the Fabaceae (Kumar 2000).

The genus Erythrina is found in the tropics and subtropics of both the New and Old Worlds (Baker \& Baker 1982). Old world species are visited and pollinated by a wide range of passerine birds (Porsch 1924; Singh 1929; Ali 1932; Docters van Leeuwan 1932) whereas most New World species are probably hummingbird pollinated (Raven 1974; Toledo 1974),

(Received 17 April 2004; Accepted 25 July 2004)

\# Corresponding author, E-mail: ajsraju@yahoo.com however, there are also reports of various passerines visiting native species of Erythrina in the New World (Skutch 1954; Timkin 1970; Snow \& Snow 1971; Leck 1974; Raven 1974). In India, Erythrina species are ornithophilous, but they are mainly visited by parrots and woodpeckers (Kumar 2000). Subramanya and Radhamani (1993) provided a list of flowering plants regularly frequented by birds based on previous works. In this list, E. variegata is reported to be visited by passerine and non-passerine birds whereas E. stricta, E. cristagalli, E. suberosa and E. subumbrans are visited by passerines only. However, there is no information on any Erythrina species regarding the floral organization, functional events of flowers in relation to the visits of birds for pollination, or fruiting behaviour. In view of this, these aspects of $E$. suberosa a common prickly tree species in the Eastern Ghats, were studied.

\section{MATERIALS AND METHODS}

Fifty-three Erythrina suberosa Roxb. trees were studied in the Lambasingi-Lotugedda area $\left(17^{\circ} 52^{\prime} \mathrm{N}\right.$; $82^{\circ} 21^{\prime} \mathrm{E}$ ), a forest stretch of about $90 \mathrm{~km}$ in the Eastern Ghats located at an elevation of $900 \mathrm{~m}$ in Visakhapatnam District, Andhra Pradesh, during February-May 2002 and 2003. Fifty flowers were sampled to record their floral morphometrics. The time of anthesis and anther dehiscence was noted by observ- 
ing marked mature buds in the field. The time and manner of anther dehiscence were noted by using a 10x hand-lens. Ten flowers were marked and bagged at the mature bud stage, opened after anthesis and nectar squeezed into a micropipette in order to measure the volume of nectar per flower; the average volume of nectar per flower was determined and expressed in $\mu$ l. Pollen grain number/anther per flower was determined for 25 flowers from different individuals following the procedure in Aluri and Subba Reddi (1994). Stigma receptivity was tested with $\mathrm{H}_{2} \mathrm{O}_{2}$ according to Dafni (1992). Breeding behaviour by autogamy (bagged and hand-pollinated), geitonogamy and xenogamy, were tested through controlled pollinations following the detailed procedure in Aluri and Subba Reddi (1994). For each mode of pollination, 50 flowers (ten each) on five different trees were used. Five hundred and fifty flowers (11 each) on five different trees were tagged and followed until fruit development to observe the rate of natural fruit and seed production. A sample of 43 fruits was used to note the seed set pattern from the pedicel end to the opposite end. Flower-visitors included only birds. They were observed with binoculars and also directly when they happened to forage at close range. Their mode of approach, landing, probing behaviour, forage collected, contact with the essential organs to effect pollination, inter-tree foraging activity, damage to the flowers, if any, were all carefully observed. Furthermore, the frequency of foraging visits for each bird species was also recorded. For this, five trees with full flowering were selected and the number of times each bird species visited the tree for nectar collection from 0600 to 1800 was noted. These observations were made on the same trees on four different days in 2002 and 2003. Then, the average number of visits made by each bird species to a tree/day was calculated.

\section{RESULTS}

E. suberosa is leafless during flowering, which occurs from early March to mid-April (Fig. 1a). The flowers are produced in terminal racemes occupying only the distal half of the inflorescence axis, thus they provide suitable perches for foraging birds (Fig. 1b). The flowers mature and open acropetally. The flowers are large, $5.3 \mathrm{~cm}$ long, bisexual and zygomorphic (Fig. 1c). The calyx is green, campanulate and bilipped. The corolla is composed of five unequal and variously coloured petals. The corolla is characteristi- cally papilionaceous and the petals are free. The scarlet-red standard petal is larger $(4.8 \mathrm{~cm}$ long) and broader than the rest; it encloses the margins of the lateral pair of maroon wing petals. These are $7 \mathrm{~mm}$ long and overlap the margins of the greenish-maroon keel petals. The keel petals $(1.1 \mathrm{~cm}$ long) form a carinal-like structure in which nectar is well seated. The ten stamens are diadelphous, with nine of them united into a bundle, and the tenth one free. The filaments are free towards the apex of the staminal tube and bear dithecous anthers. The stamens vary slightly in length, five are one length, four another length, and the free stamen lies below the level of the bundled stamens. The stamens are almost at the same level with respect to making contact with a bird's bill or breast as it takes nectar from a flower. The ovary is semi-inferior with one carpel having seven (rarely eight) ovules in it. The ovary is enclosed by the staminal tube, but the style protrudes through the staminal tube. The style is $11 \mathrm{~mm}$ long and ends in a minute stigma, and lies behind the forward level of the anthers.

The flowers open early in the morning from 0500-0600. Anthers dehisce via longitudinal slits about one hour before flowers open. Flowers produce an average of $33,870 \pm 27$ (SD) pollen grains. Nectar is secreted prior to flower opening and amounts to $140 \pm 4.6$ (SD) $\mu$ l per flower. Nectar is well protected from direct exposure to sunlight by the keel and wing petals. The stigma is receptive to pollen from anthesis onwards and remains so until the evening of the 2nd day. The flowers remain in place for three days if not disturbed by flower visitors.

Hand-pollination tests indicated $88 \%$ pod-set occurred through xenogamy and 40\% through geitonogamy, with no pod-set with autogamy (Table 1). Each fruited flower matured without abortion. Fruit development is very fast, taking only about three weeks to reach maturity. Fruit maturity and dehiscence is almost immediately followed by the initiation of leaf-flush. The natural fruit set rate was only $10 \%$ (Table 1). The fruited flowers produced 1-4 seeds with $63 \%$ produced two-seeded pods (Fig. 2). Seed set was more frequent from the ovules in numbers two and five positions in the ovary (Fig. 3). Seed set rate was $26 \%$. Mature pods dehisce explosively (Fig. 1d) to scatter their seeds.

Twelve species of passerine birds in six families were identified as visiting flowers and taking nectar (Table 2, Fig. 1f-k). Of these, three species (Common Rosefinch Carpodacus erythrinus, Red-whiskered 

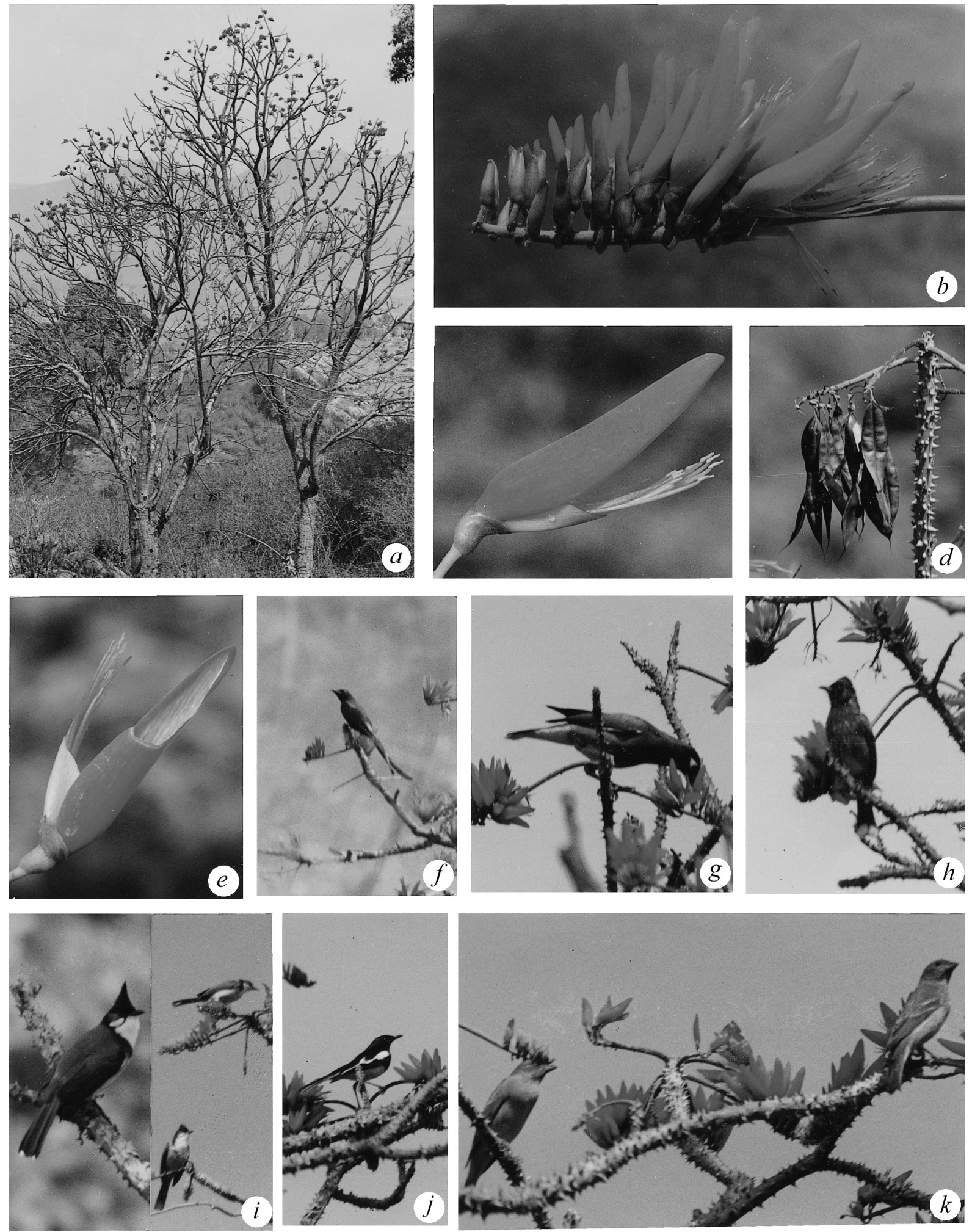

Fig. 1. Erythrina suberosa: a, flowering, leafless trees; b, inflorescence; c, flower; d, explosive pods; e, anterior part of standard petal cut by Black Drongo; f-k: bird visitors; f, Black Drongo; g, Indian Myna; h, Red-vented Bulbul; i, Red-whiskered Bulbul; j, Magpie-Robin; k, Common Rosefinch (left, male; right, female). 


\section{A. J. S. RAJU and S. P. RAO}

Table 1. Fruit set rate in controlled pollination treatments in Erythrina suberosa

\begin{tabular}{lccc}
\hline \multicolumn{1}{c}{ Treatment } & $\begin{array}{c}\text { No. of flowers } \\
\text { pollinated/tagged }\end{array}$ & $\begin{array}{c}\text { No. of flowers } \\
\text { set fruit }\end{array}$ & $\begin{array}{c}\text { Percentage } \\
\text { of fruit set }\end{array}$ \\
\hline Autogamy (bagged without hand-pollination) & 50 & 0 & 0 \\
Autogamy (hand-pollinated) & 50 & 0 & 0 \\
Geitonogamy & 50 & 20 & 40 \\
Xenogamy & 50 & 44 & 88 \\
Open-pollination & 550 & 55 & 10 \\
\hline
\end{tabular}

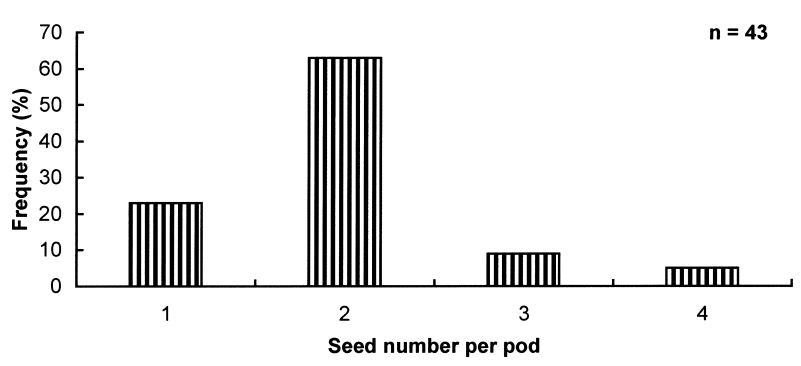

Fig. 2. Frequency occurrence of seeds per pod in E. suberosa.

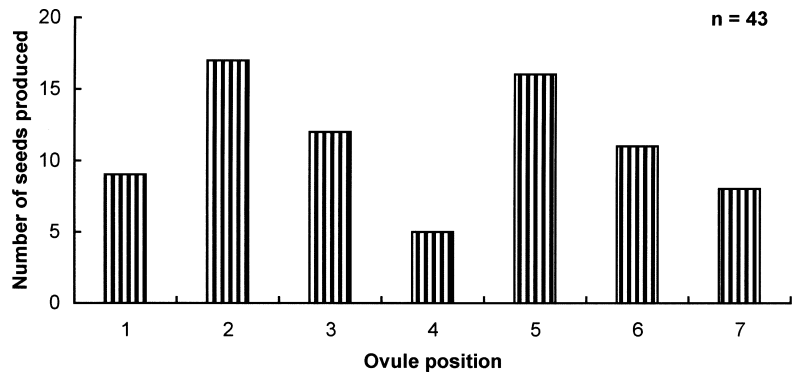

Fig. 3. Seed production rate in relation to ovule position, from the pedicel tip in E. suberosa.

Table 2. Passerine bird visitors to the flowers of Erythrina suberosa

\begin{tabular}{|c|c|c|c|c|}
\hline \multicolumn{2}{|c|}{ Bird } & \multirow{2}{*}{ Common name } & \multirow{2}{*}{$\begin{array}{l}\text { Average no. of } \\
\text { visits/tree/day }\end{array}$} & \multirow{2}{*}{$\begin{array}{c}\text { Percentage } \\
\text { of visits }\end{array}$} \\
\hline Family & Scientific name & & & \\
\hline Dicruridae & Dicrurus adsimilis & Black Drongo & 75 & 9 \\
\hline \multirow[t]{4}{*}{ Sturnidae } & Sturnus pagodarum & Brahminy Myna & 91 & 10 \\
\hline & Acridotheres ginginianus & Bank Myna & 16 & 2 \\
\hline & A. tristis & Indian Myna & 69 & 8 \\
\hline & A. fuscus & Jungle Myna & 74 & 8 \\
\hline \multirow[t]{3}{*}{ Pycnonotidae } & Pycnonotus melanicterus & Black-headed Yellow Bulbul & 11 & 1 \\
\hline & P. cafer & Red-vented 1 Bulbu & 143 & 16 \\
\hline & P. jocosus & Red-whiskered Bulbul & 151 & 17 \\
\hline \multirow[t]{2}{*}{ Muscicapidae } & Turdoides striatus & Jungle Babbler & 9 & 1 \\
\hline & Copsychus saularis & Magpie-Robin & 57 & 7 \\
\hline Zosteropidae & Zosterops palpebrosa & White-eye & 9 & 1 \\
\hline Fringillidae & Carpodacus erythrinus & $\begin{array}{l}\text { Common } \\
\text { Rosefinch }\end{array}$ & 182 & 20 \\
\hline
\end{tabular}

Bulbul Pycnonotus jocosus and Red-vented Bulbul $P$. cafer) made over 100 visits/tree/day; five species (Brahminy Myna Sturnus pagodarum, Black Drongo Dicrurus adsimilis, Jungle Myna Acridotheres fuscus, Indian Myna A. tristis and Magpie Robin Copsychus saularis) made 57-91 visits/tree/day; and the remaining four species made fewer than 20 visits/tree/day
(Table 2). All 12 species perched first on the inflorescence axis, moved toward the flower, then thrust their bill and head into the flower. While probing the flowers the birds invariably contacted the stamens and stigma with their throat or breast. After the birds took nectar, they moved backward and raised their beak to swallow nectar. The Black Drongo, however, cut the 
anterior part of the standard petal to reach the nectar more easily and affected pollination (Fig. 1e). The birds visited the flowers throughout the day, but did so most often during the morning. The inflorescences were found to rock and swing when large birds such as rosefinches and mynas hopped from one inflorescence to another, and as a result withered and withering flowers fell off. Birds were found to move frequently between $E$. suberosa trees in search of more nectar, and mynas and bulbuls also visited the flowers of Bombax ceiba for more nectar.

\section{DISCUSSION}

Erythrina is a pantropical genus (Cruden \& Toledo 1977) that shows remarkable variation in inflorescence orientation and floral organization. In paleotropical species, inflorescences are oriented horizontally and flowers are confined to the distal part of the inflorescence, providing a standing place for bird visitors. These species are described as being pollinated by passerine birds that require a standing place on the inflorescence for probing the flowers (Baker et al. 1983). In neotropical species, similar inflorescence orientation and floral organization have been reported in Erythrina species that have also been reported to be pollinated by passerine birds, however, there are also Erythrina species that are pollinated by hummingbirds. In these species, the inflorescence is almost vertical in orientation and the flowers are placed in such a way that they can be reached by hummingbirds hovering outside the flowers in order to take nectar (Baker et al. 1983). Erythrina suberosa is an Asian species and occurs in India. In this species, the inflorescence is oriented horizontally and the flowers occur in the distal half, providing a standing place for passerine birds for probing the flowers as reported by Baker et al. (1983) for paleotropical Erythrina species.

Bird-pollinated flowers open during the day, are predominantly red, odourless, and larger than insectpollinated flowers. Their inflorescences are few in number, but they are long-lived for long-term attraction to birds. They normally have inferior ovaries, which confer protection to the ovules against the probing bills of birds. Their stamens and stigma brush against the breast or head of the visiting birds. The flowers produce copious sugary nectar, which is well protected from nectar thieves (Stiles 1978; Faegri \& van der Pijl 1979; Meeuse \& Morris 1984; Kumar 2000). E. suberosa is typically ornithophilous, showing all of these characteristics. Furthermore, the flower of E. suberosa is papilionaceous with a welldeveloped standard petal and poorly developed wing and keel petals exposing the stamens, style and stigma to the aerial environment. The standard petal stands in an upright position and is the most conspicuous part of the flower and it is this that attracts pollinators. These characteristics have previously been reported for a range of bird-pollinated species in the Fabaceae (Jaeger 1961).

In seasonal tropical forests, many trees are pollinated by large, far-flying, systematic pollinators (Kumar 2000). E. suberosa trees bloom while still leafless during the dry season, when its red flowers are attractive to avian visitors. Subramanya and Radhamani (1993) reviewed information on bird and bat pollination in the Western Ghats forests of India and provided a list of birds that frequent the flowers of different plant species for nectar. They documented 15 species of passerine birds visiting the flowers of E. suberosa for nectar in the Western Ghats. The birds included Dicrurus adsimilis, D. paradiseus, Acridotheres tristis, Corvus splendens, Chloropsis cochinchinensis, Pycnonotus jocosus, P. luteolus, Hypsipetes madagascarensis, Turdoides striatus, $T$. affinis, Orthotomus sutorius, Turdus merula, Nectarinia zeylonica, N. lotenia and N. asiatica. All these except $H$. madagascarensis occur in the present study area (Krishna Raju 1985). Of these, birds such as $D$. adsimilis, A. tristis, P. jocosus and T. striatus were found to visit $E$. suberosa flowers for nectar. In addition, other passerine bird species also visited the flowers to drink nectar. All these birds perch on the proximal region of the inflorescence and move forward while probing the flowers. Acropetal anthesis of the inflorescence is an added advantage for passerine birds to probe flowers. While probing for nectar, the birds contact the stamens, style and stigma with their head or breast, which result in them being dusted with pollen and so transferring pollen between flowers. Birds have considerable energy requirements and the nectar production of one Erythrina tree may be insufficient for the energetic requirements of even one bird. As a result, birds are forced to make frequent visits to different trees. All of the birds we observed frequently visit different trees to quench their thirst for nectar and in so doing they effect cross-pollination.

Although hand-pollination tests indicate that $E$. suberosa is partly self-compatible, setting fruit only through geitonogamy, it is nevertheless highly cross- 
compatible and shows maximum fruit set through xenogamy. This breeding system is indicative of facultative xenogamy (Cruden 1977), which essentially requires pollen vectors. Even though self-pollination can occur, most fruit set is through cross-pollination. Because, visiting birds make frequent visits to different $E$. suberosa trees and such foraging activity may result in more cross-pollen transfer. Despite the hectic foraging activity of birds, E. suberosa is able to produce only $10 \%$ fruit set, but this low rate is compensated for by higher seed set. Seed set pattern in the mature pods indicated that most of the pods produce only two seeds although there are seven or rarely eight ovules in the ovary. Furthermore, the positions of the developed seeds in the pods examined revealed that there is a strong positional preference for seed development; ovules in the number two and five position (from the pedicel tip to the stigmatic end) seem to produce most of the seeds. This observation does not agree with Joshi et al. (1993) who reported that positions 3, 4 and 5 may be the most preferred ones for seed development. Therefore, we suggest that further work is needed to confirm which positions of ovules are the most preferred for seed development.

\section{ACKNOWLEDGEMENTS}

Financial support from the Ministry of Environment and Forests, Government of India, New Delhi through a Major Research Project (No. 30/12/97-RE) to AJSR is gratefully acknowledged. We thank several anonymous referees for their comments, which helped to improve the manuscript.

\section{REFERENCES}

Ali SA (1932) Flower-birds and bird-flowers in India. J Bombay Nat Hist Soc 35: 573-605.

Aluri RJS \& Subba Reddi C (1994) Pollination ecology and mating system of the weedy mint, Leonotis nepetaefolia R.Br. in India. Proc Indian Nat Sci Acad B60: 255-268.

Baker HG \& Baker I (1982) Chemical constituents of nectar in relation to pollination mechanisms and phylogeny. In: Nitecki MH (ed) Biochemical aspects of evolutionary biology. pp 131-171. The University of Chicago Press, Chicago.

Baker HG, Bawa KS, Frankie GW \& Opler PA (1983) In: Golley FB (ed) Tropical rain forest ecosystems. Elsevier Scientific Publishing Company, New York.

Cruden RW (1977) Pollen-ovule ratios: A conservative indicator of breeding systems in flowering plants.
Evolution 31: 32-46.

Cruden RW \& Toledo VM (1977) Oriole pollination of Erythrina breviflora (Leguminosae): Evidence for a polytropic view of ornithophily. Plant Syst Evol 126: 393-403.

Dafni A (1992) Pollination ecology: a practical approach. Oxford University Press, New York.

Docters van Leeuwan WM (1932) Vogelbesuch an den Bluten von einigen Erythrina-Arten auf Java. Ann Jard Bot Buitenz 42: 46-95.

Faegri K \& van der Pijl L (1979) The principles of pollination ecology. Pergamon Press, Oxford.

Jaeger P (1961) The wonderful life of flowers. EP Dutton \& Co, Inc, New York.

Joshi NV, Uma Shaankar R \& Ganeshaiah KN (1993) The 'neighbour effect' and its role in shaping the positional pattern of seed development in fruits: an illustration from the pods of Erythrina suberosa. Curr Sci 65: 234-238.

Krishna Raju KSR (1985) A contribution to the ornithology of Visakhapatnam region. Kingfisher Special Issue.

Kumar HD (2000) Plant-animal interactions. Affiliated East-West Press Private Ltd, New Delhi.

Leck C (1974) Further observations of nectar feeding by orioles. Auk 91: 162-163.

Meeuse B \& Morris S (1984) The sex life of flowers. Facts on File, New York.

Porsch O (1924) Vogelblumen-Studien I. Jahrb Wiss Bot 63: 553-605.

Raven PH (1974) Erythrina (Fabaceae): Achievements and opportunities. Lloydia 37: 321-331.

Singh TCN (1929) A preliminary note on the pollination of the coral tree (Erythrina indica Lamk.). J Bombay Nat Hist Soc 33: 460-462.

Skutch AF (1954) Life histories of Central American birds. Pacific coast avifauna No 31. Cooper Ornithological Society, Berkeley.

Snow BK \& Snow DW (1971) The feeding ecology of tanagers and honeycreepers in Trinidad. Auk 88: 291-322.

Stiles FG (1978) Temporal organization of flowering among the hummingbird food plants of a tropical wet forest. Biotropica 10: 194-210.

Subramanya S \& Radhamani TR (1993) Pollination by birds and bats. Curr Sci 65: 201-209.

Timkin RL (1970) Food habits and feeding behaviour of the Baltimore Oriole in Costa Rica. Wilson Bull 82: 184-188.

Toledo VM (1974) Observations on the relationship between hummingbirds and Erythrina species. Lloydia 37: 482-487. 